\title{
Retrieval of aerosol properties from ceilometer and photometer measurements: long-term evaluation with in situ data and statistical analysis at Montsec (southern Pyrenees)
}

\author{
Gloria Titos $^{1, a}$, Marina Ealo ${ }^{1,2}$, Roberto Román ${ }^{3,4}$, Alberto Cazorla $^{3}$, Yolanda Sola ${ }^{2}$, Oleg Dubovik ${ }^{5}$, \\ Andrés Alastuey ${ }^{1}$, and Marco Pandolfi ${ }^{1}$ \\ ${ }^{1}$ Institute of Environmental Assessment and Water Research (IDAEA), CSIC, Barcelona, Spain \\ ${ }^{2}$ Group of Meteorology, Department of Applied Physics, Faculty of Physics, University of Barcelona, Barcelona, Spain \\ ${ }^{3}$ Andalusian Institute for Earth System Research, IISTA-CEAMA, Granada, Spain \\ ${ }^{4}$ Grupo de Óptica Atmosférica (GOA), Universidad de Valladolid, Valladolid, Spain \\ ${ }^{5}$ Laboratoire d'Optique Atmosphérique (LOA), Université de Lille, Lille, France \\ ${ }^{a}$ now at: Applied Physics Department, University of Granada, Granada, Spain
}

Correspondence: Gloria Titos (gtitos@ugr.es)

Received: 9 December 2018 - Discussion started: 4 February 2019

Revised: 7 May 2019 - Accepted: 29 May 2019 - Published: 19 June 2019

\begin{abstract}
Given the need for accurate knowledge of aerosol microphysical and optical properties with height resolution, various algorithms combining vertically resolved and column-integrated aerosol information have been developed in the last years. Here we present new results of vertically resolved extensive aerosol optical properties (backscattering, scattering and extinction) and volume concentrations retrieved with the GRASP (Generalized Retrieval of Aerosol and Surface Properties) algorithm over a 3-year period. The range-corrected signal (RCS) at $1064 \mathrm{~nm}$ measured with a ceilometer and the aerosol optical depth (AOD) and sky radiances from a sun/sky photometer have been used as input for this algorithm. We perform a detailed evaluation of GRASP retrievals with simultaneous in situ measurements performed at the same height, at the Montsec mountaintop observatory (MSA) in the Pre-Pyrenees (northeastern Spain). This is the first long-term evaluation of various outputs of this algorithm; previous evaluations focused only on the study of aerosol volume concentration for short-term periods. In general, our results show good agreement between techniques although GRASP inversions yield higher values than those measured in situ. The statistical analysis of the extinction coefficient vertical profiles shows a clear seasonality as well as significant differences depending on the air mass origin. The observed seasonal cycle is mainly modulated by a higher development of the atmospheric boundary layer (ABL) dur-
\end{abstract}

ing warm months, which favors the transport of pollutants to MSA, and higher influence of regional and North African episodes. On the other hand, in winter, MSA is frequently influenced by free-troposphere conditions and venting periods and therefore lower extinction coefficients that markedly decrease with height. This study shows the potentiality of implementing GRASP in ceilometer and lidar networks for obtaining aerosol optical properties and volume concentrations at multiple sites, which will definitely contribute to enhancing the representativeness of the aerosol vertical distribution as well as to providing useful information for satellite and global model evaluation.

\section{Introduction}

Atmospheric aerosol particles interact directly with the incident solar radiation by either scattering or absorbing light. These aerosol-radiation as well as the aerosol-cloud interactions influence the Earth's radiative budget and therefore have an impact on climate. Aerosol particles are considered the atmospheric constituents with the largest uncertainty in global climate forcing estimations (IPCC, 2013). Their high spatial, vertical and temporal variability is one of the key factors contributing to their large uncertainty (IPCC, 2013). 
During the last years, a great effort has been made by the Aerosols, Clouds, and Trace gases Research InfraStructure (ACTRIS, https://www.actris.eu, last access: 1 May 2019) community to extend the temporal and spatial coverage of aerosol property sampling and to harmonize measurement protocols to increase their representativeness and the comparability among sites and between measurement techniques (i.e., in situ versus remote sensing). In situ observatories are widely distributed and cover a large variety of atmospheric conditions (urban, rural, background and remote sites). Moreover, in situ instrumentation is able to provide a complete set of information in terms of chemical, optical and microphysical aerosol properties. The main drawback of in situ observatories is that they are only representative of the atmospheric layer closest to the surface and might not be useful to infer aerosol radiative properties at elevated layers (Rosati et al., 2016). For this reason, vertically resolved aerosol observations are needed to complement surface in situ measurements and column-integrated observations from satellites or ground-based photometers. Lidar systems are frequently used for profiling aerosol optical properties, and, depending on the lidar capabilities and availability of co-located photometer measurements, vertical profiles of aerosol microphysical properties can be retrieved as well by using inversion algorithms (Chaikovsky et al., 2008, 2016; Lopatin et al., 2013).

One of the recently developed inversion algorithms is the Generalized Retrieval of Aerosol and Surface Properties (GRASP; Dubovik et al., 2014; https://www.grasp-open. com/, last access: 1 May 2019) code that uses the heritage of the AERONET (Aerosol Robotic Network) inversion scheme (e.g., Dubovik and King, 2000; Dubovik et al., 2006). It is a versatile and open-source algorithm capable of obtaining optical and microphysical aerosol properties from different sets of measurements (Kokhanovsky et al., 2015; Espinosa et al., 2017; Torres et al., 2017; Román et al., 2017, 2018). In particular, GRASP allows the user to combine aerosol optical depths (AODs), sky radiances and range-corrected lidar signal (RCS) values to retrieve columnar and vertically resolved aerosol properties. Román et al. (2018) proposed a similar approach but using the RCS values at only one wavelength measured with ceilometer instead of using multi-wavelength lidar RCS values as done before. The retrieved vertical profiles of aerosol volume concentration showed good agreement with in situ measurements from an aircraft campaign and with in situ measurements from a nearby mountain station during a summer campaign in southern Spain (Román et al., 2018). The use of ceilometer measurements in the GRASP algorithm can be a significant advance towards a better representation of aerosol properties with vertical resolution since ceilometers are cheaper, require less supervision, provide continuous measurements and are more extensively distributed compared to more sophisticated lidar systems (Wiegner et al., 2014; Cazorla et al., 2017; Dionisi et al., 2018). However, the main drawback of this approach is that sun/sky photometer measurements are only available during daytime and under low-cloudiness conditions. Other methodologies, such as the absolute calibration of the ceilometer (Wiegner and Geiß, 2012), are able to overcome this issue and provide quantitative backscatter profiles during day and nighttime. Quantitative ceilometer profiles could be used for evaluating dust forecast models (Tsekeri et al., 2017) such as the BSC-DREAM8b, as input to radiative transfer models (Granados-Muñoz et al., 2019), or can be assimilated in global models (Chen et al., 2018). This application represents a step forward in the classical use of ceilometers that were originally developed for cloud base detection (e.g., Martucci et al., 2010; Wiegner et al., 2014).

The potential of this new technique motivates the present study in which the GRASP code is used to retrieve long-term vertical profiles of aerosol optical and microphysical properties combining ceilometer and AERONET sun/sky photometer measurements over a 3-year period. The main objective of this paper is to evaluate the performance of the retrieved aerosol products by GRASP combining ceilometer and photometer measurements using as reference the in situ measurements performed at the Montsec Global Atmosphere Watch (GAW) station (MSA, 1570 m a.s.l., NE Spain). Additionally, a statistical analysis of the vertical structure of aerosol properties based on the 3 years of GRASP retrievals at MSA is presented.

\section{Experimental site and instrumentation}

\subsection{Montsec observatory}

Measurements used in this study were performed in the northeastern Iberian Peninsula, with most of them at the Montsec mountaintop station (MSA; $42^{\circ} 3^{\prime} \mathrm{N}, 0^{\circ} 44^{\prime} \mathrm{E}$, $1570 \mathrm{~m}$ a.s.1.), located in the facilities of the Montsec Astronomic Observatory (OAdM, http://oadm.ieec.cat/, last access: 1 May 2019). The MSA continental background site is part of the Catalan Air Quality Network (Xarxa de Vigilància i Previsió de la Contaminació Atmosfèrica, http:// territori.gencat.cat/, last access: 1 May 2019), and it is integrated in the European research infrastructure ACTRIS and in the Global Atmosphere Watch (GAW) program. It is a remote high-altitude station situated in the southern side of the Pre-Pyrenees at the Montsec d'Ares mountain. This region is sparsely populated and isolated from large urban and industrial agglomerations $(140 \mathrm{~km}$ from Barcelona to the northwest and $30 \mathrm{~km}$ from the largest city in the region). The prevailing atmospheric conditions are characteristic of Mediterranean climate, with long dry periods, sporadic but intense rains, and a prevalence of local and regional atmospheric air mass circulations and Saharan dust intrusions (Ripoll et al., 2014; Ealo et al., 2016). 


\subsection{In situ measurements}

Aerosol particles' light-scattering $\left(\sigma_{\mathrm{sp}}\right)$ and hemisphericbackscattering $\left(\sigma_{\mathrm{bsp}}\right)$ coefficients were measured at three wavelengths $(450,525$ and $635 \mathrm{~nm})$ with an LED-based integrating nephelometer (model Aurora 3000, ECOTECH Pty, Ltd., Knoxfield, Australia) with 5 min time resolution. The aerosol flow in the nephelometer was set to $5 \mathrm{~L} \mathrm{~min}^{-1}$. Measurements were performed at dry conditions $(\mathrm{RH}<40 \%)$ by using the internal RH-control function of the nephelometer that slightly heats the sampled air when the RH is above the threshold value. The nephelometer is periodically calibrated (four times per year) with $\mathrm{CO}_{2}$ and filtered air. Zero adjustments are performed every midnight using internally filtered particle-free air. The Aurora 3000 nephelometer used in this study operates by collecting light scattered within the angular range $10-171^{\circ}$ (Müller et al., 2011a). The main source of error is the truncation in the forward direction $\left(0-10^{\circ}\right)$ due to the inability of the nephelometer to sense near-forward scattering, which is an increasingly dominant part of the total scattering for large particles (Anderson et al., 1996). Nonidealities due to truncation errors have been corrected following the scheme described by Müller et al. (2011a). The detection limits of the nephelometer over $1 \mathrm{~min}$ averaging time are $0.11,0.14$ and $0.12 \mathrm{Mm}^{-1}$ for total scattering at 450,525 and $635 \mathrm{~nm}$, respectively, and $0.12,0.11$ and $0.13 \mathrm{Mm}^{-1}$ for backscattering (Müller et al., 2011a).

The aerosol light-absorption coefficient, $\sigma_{\mathrm{ap}}$, was measured with a Multi-Angle Absorption Photometer (MAAP, model 5012, Thermo) at $637 \mathrm{~nm}$ (Müller et al., 2011b). A detailed description of the method is provided by Petzold and Schönlinner (2004). The MAAP draws the ambient air at constant flow rate of $16.7 \mathrm{~L} \mathrm{~min}^{-1}$ and provides $1 \mathrm{~min}$ values. The detection limit of the MAAP instrument is lower than $0.6 \mathrm{Mm}^{-1}$ over 2 min integration. The total method uncertainty for the particle light-absorption coefficient inferred from MAAP measurements is around $12 \%$ (Petzold and Schönlinner, 2004).

An aerosol optical counter (GRIMM spectrometer, model 1129-Sky-OPC) was used to measure particle number concentrations in 31 size bins, for particles in the diameter size range from 0.25 to $32 \mu \mathrm{m}$ at $5 \mathrm{~min}$ time resolution. The working principle of this instrument is based on multichannel light-scattering optics (Grimm and Eatough, 2009) in which the intensity of the measured scattered light is related to the size of the particles. Volume size distributions were derived from the number size distribution assuming spherical particles.

All in situ measurements were performed at the MSA station and have been converted to ambient temperature and pressure using the measurements from an automatic and collocated weather station. Measurements were performed at low relative humidity ( $\mathrm{RH}<40 \%$ ), as recommended by the World Meteorological Organization (WMO/GAW, 2003) and ACTRIS infrastructure.

\subsection{Passive remote sensing measurements}

Measurements of column-integrated aerosol properties were determined with a CE-318 sun/sky photometer (Cimel Electronique, France) included in AERONET (Holben et al., 1998) and located at the MSA observatory. This instrument performs direct sun measurements with a $1.2^{\circ}$ full field of view at least at $440,675,870$ and $1020 \mathrm{~nm}$, which are used to derive AOD at these wavelengths. The sky radiance measurements (almucantar configuration) are also carried out at 440, 675,870 and $1020 \mathrm{~nm}$. A full description of the AERONET products obtained from this instrument can be found in Holben et al. (1998). In this work, AOD and sky radiances, both at $440,675,870$ and $1020 \mathrm{~nm}$, from version 2 of AERONET level 1.5 data are used.

\subsection{Active remote sensing measurements}

Vertical profiles of RCS at $1064 \mathrm{~nm}$ were performed with a Jenoptik CHM 15k Nimbus (G. Lufft Mess- und Regeltechnik GmbH, Germany) ceilometer that includes a pulsed $\mathrm{Nd}$ :YAG laser, emitting at $1064 \mathrm{~nm}$. The energy emitted per pulse is $8 \mu \mathrm{J}$ and the duration of each pulse is between 1 and $5 \mathrm{~ns}$ with a repetition frequency of $6.5 \mathrm{kHz}$. The maximum height of the signal is $15.36 \mathrm{~km}$ a.g.l., equivalent to 1024 range bins. The ceilometer is located at $800 \mathrm{~m}$ a.s.l., at the Center for the Observation of the Universe (COU, http://www.parcastronomic.cat/, last access: 1 May 2019). The horizontal distance between the ceilometer and the MSA station is less than $2.5 \mathrm{~km}$. This instrument operates continuously with a temporal resolution of $1 \mathrm{~min}$ and a spatial resolution of $15 \mathrm{~m}$. The RCS profiles provided by the instrument are overlap-corrected using the manufacturer's overlap function. In addition, according to this function, the overlap of the telescope and the laser beam is greater than $85 \%$ beyond $770 \mathrm{~m}$ from the ceilometer. Thus, the effect of the overlap at the height of the MSA observatory (1570 $\mathrm{m}$ a.s.l.) is expected to be low.

\section{GRASP retrievals}

GRASP code is mainly based on two independent modules: (1) the forward module consisting of a radiative transfer and aerosol model which simulates the radiative measurements for a given aerosol scenario, and (2) the numerical inversion module which is not related to the physical nature of the inverted data (Dubovik et al., 2011, 2014) and is mathematically based on the multi-term least square method (Dubovik and King, 2000). Detailed description of the GRASP working principle using sun/sky photometer and RCS data can be found in Lopatin et al. (2013), where the GARRLiC (Generalized Aerosol Retrieval from Radiometer and Lidar Combined data) scheme, which is part of GRASP code, is explained. 
In this study, we follow the inversion strategy named GRASP $_{\text {pac }}$ (with subscript meaning "photometer and ceilometer") introduced by Román et al. (2018). A GRASP $_{p a c}$ retrieval is done for each sky radiance almucantar sequence available from AERONET if sky radiances and ceilometer measurements satisfy cloud-free conditions. The following measurements are used in the GRASP code for each retrieval: (1) the cloud-screened sky radiance and AOD at 440, 675, 870 and $1020 \mathrm{~nm}$ (AERONET version 2 level 1.5); and (2) the normalized ceilometer RCS at $1064 \mathrm{~nm}$, previously cloud-screened, smoothed and averaged in a \pm 15 min window centered in the photometer measurement time, at $60 \mathrm{log}$-spaced heights as in Lopatin et al. (2013). The minimum height of these 60 values corresponds to the MSA altitude. The maximum height selected for the $60 \mathrm{log}$-spaced bins is $7000 \mathrm{~m}$ above MSA, since aerosol layers are rarely detected above this height and the ceilometer signal is usually too noisy at higher altitudes due to the low power of the ceilometer's laser. The RCS at these $60 \mathrm{log}$-spaced bins is averaged and then normalized by dividing each value by the integrated RCS between the minimum and maximum heights. In addition, the bidirectional reflectance distribution function (BRDF) is needed to make the GRASP ${ }_{\text {pac }}$ retrievals, and, to this end, an $8 \mathrm{~d}$ climatology (2000-2014) of the MCD43C1 product (V005 MODIS Terra+Aqua BRDF/Albedo 16-Day L3 0.05Deg CMG) of MODIS (Moderate Resolution Imaging Spectroradiometer) is used (Schaaf et al., 2011).

Since ceilometer measurements are limited to a single wavelength, it is not possible to vertically differentiate between aerosol modes/types, and therefore vertical profiles of intensive variables such as the single-scattering albedo (SSA), lidar ratio (LR) or effective radius are assumed to be vertically constant by this method. As a result, for each GRASP $_{\text {pac }}$ retrieval we obtain aerosol profiles (at 60 points) of backscatter at $180^{\circ}$; of scattering, extinction and absorption coefficients at 440,675, 870, 1020 and $1064 \mathrm{~nm}$; and also of aerosol size distribution (but without changes in the effective radius with height) and the aerosol volume concentration. The estimated uncertainty for the backscatter coefficient retrieved with GRASP ${ }_{\mathrm{pac}}$ is $31 \%$, and it is $21 \%$ for the extinction coefficient and the volume concentration (Román et al., 2017). The uncertainty in the backscatter profiles retrieved with GRASP $\mathrm{pac}_{\text {is }}$ is higher than the estimated uncertainty by Wiegner and Geiß (2012) for the absolute calibration method (10\%). Since the in situ measurements and GRASP $_{\text {pac }}$ retrievals provide different information with respect to the aerosol backward-scattering properties (hemispheric backscattering versus backscatter at $180^{\circ}$ ), the direct comparison between both techniques is not possible. To have a sense of the performance of the GRASP pac $_{\text {backscatter re- }}$ trieval, for the comparison we have assumed that the scattering into the backward hemisphere is the same in all directions. Therefore, we have extrapolated the backscatter at $180^{\circ}$ to the angular range $90-180^{\circ}$ in order to make it com- parable with the backscattering coefficient measured with the nephelometer. This assumption constitutes an additional source of error since the actual angular scattering distribution is not known and typically backscatter at $180^{\circ}$ is larger than at smaller angles.

\section{Results and discussion}

\subsection{GRASP $_{\text {pac }}$ - in situ comparison}

\subsubsection{Optical properties comparison}

In situ extensive aerosol optical properties (i.e., hemisphericbackscattering, scattering and extinction coefficients) measured at MSA over a 3-year period (April 2014-March 2017) are used for evaluating the retrieval of aerosol optical properties from a ceilometer and a sun/sky photometer using the GRASP $_{\text {pac }}$ method in a long-term frame. Previous evaluations of this algorithm with in situ data focused on aircraft campaigns (2-3 study cases) (e.g., Benavent-Oltra et al., 2017; Tsekeri et al., 2017) or short-term periods (Román et al., 2018). Figure 1 shows the comparison between the GRASP $_{\text {pac }}$ retrievals and in situ-measured coefficients at low ambient $\mathrm{RH}\left(\mathrm{RH}_{\text {ambient }}<50 \%\right)$. This restriction has been imposed to avoid cases affected by hygroscopic growth and consequent enhancement of the optical coefficients detected by the remote sensing instrumentation. To merge both

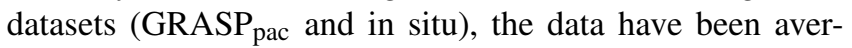
aged in $1 \mathrm{~h}$ intervals. The comparison has been performed at $1570 \mathrm{~m}$ a.s.l., where the in situ instrumentation is located and coinciding with the first height of the GRASP ${ }_{\mathrm{pac}}$ retrievals. Therefore, the following results and associated discussion on the comparison between GRASP $\mathrm{pac}_{\mathrm{pa}}$ and in situ measurements refer exclusively to this height. In general, the GRASP $_{\text {pac }}$ retrievals are in agreement with the in situ measurements. The coefficients of determination span from 0.49 for the backscattering coefficient to 0.77 for the scattering coefficient and 0.73 for the extinction coefficient (see details in Fig. 1). For both the aerosol light-scattering and the extinction coefficients the slope and intercept of the regression are $>1$, while for the backscattering coefficient the slope is $<1$. Figure 2 shows the absolute differences between optical parameters measured in situ and retrieved by GRASP pac $_{\text {}}$ optical parameters. The frequency distributions of the absolute errors (in situ minus GRASP ${ }_{\text {pac }}$ values) for the scattering and extinction coefficients are tailed towards negative values evidencing an overestimation of GRASP ${ }_{p a c}$ retrievals compared with in situ measurements. For the extinction coefficient, Herreras et al. (2018) showed good agreement between the integrated extinction profiles derived with GRASP $_{\mathrm{pac}}$ and AOD from sun photometers located at various heights $\left(R^{2}>0.6\right)$. For the backscattering coefficient, Fig. 2 shows that GRASP ${ }_{\text {pac }}$ also overestimates the in situ measurements, but the frequency distribution of the abso- 
lute errors is more symmetrically distributed around 0 . The overestimation of GRASP $\mathrm{pac}_{\mathrm{p}}$-retrieved backscattering coefficients is in agreement with the assumption made to convert the backscatter coefficient at $180^{\circ}$ provided by GRASP ${ }_{\text {pac }}$ into a hemispheric-backscattering coefficient in order to perform the comparison with the in situ measurements (see Sect. 3). As the backscatter at $180^{\circ}$ is typically larger than at smaller angles, this overestimation was expected. However, since overestimation of the total scattering and extinction coefficients also occurs, it is difficult to discern whether this overestimation originates in the GRASP ${ }_{\text {pac }}$ retrieval or in the assumption made to compare with the in situ data. On the other hand, this assumption might be contributing to lower the correlation between the backscattering coefficient from GRASP $_{\mathrm{pac}}$ and in situ measurements in comparison with the results obtained for the scattering and extinction coefficient comparison (Fig. 1), which shows higher correlation coefficients.

Figure 3 shows the relationship between the scattering and extinction coefficients measured in situ and retrieved by GRASP $_{\text {pac }}$. The color scale represents the difference in the single-scattering albedo measured in situ and retrieved with GRASP $_{\mathrm{pac}}$. For the in situ data, there is a linear trend between scattering and extinction coefficients $\left(R^{2}=1\right)$, denoting that the aerosol light extinction is dominated by the scattering process, which is in accordance with previous in situ studies performed at MSA (Pandolfi et al., 2014). On the contrary, for the GRASP pac retrievals the correlation is also good but the data points deviate from the $1: 1$ line as the difference in the SSA between in situ and GRASP ${ }_{p a c}$ increases (yellowish colors). In general, GRASP ${ }_{\text {pac }}$ retrievals yield lower SSA values (average SSA of $0.88 \pm 0.14$ ) compared with in situ SSA $(0.93 \pm 0.04)$. These discrepancies in the absorption could be related to the differences in the SSA at ground level (as measured in situ) and the SSA associated with the total atmospheric column (GRASP pac $_{\text {) }}$ due to absorbing aloft layers. However, the largest disagreements (yellowish colors in Fig. 3b) coincide with Atlantic air mass influence, which as shown in Sect. 4.2, are characterized by low aerosol load and low impact of decoupled aerosol layers. On the other hand, Andrews et al. (2017) showed a systematic difference in the SSA from AERONET retrievals compared with integrated in situ profiles, revealing that AERONET retrievals yield higher aerosol absorption than in situ measurements, especially at low aerosol load. MSA is a remote site with predominantly low aerosol load and low contribution of absorbing particles. Furthermore, Román et al. (2018) found with synthetic data

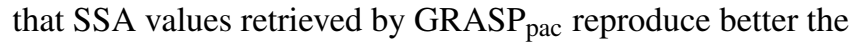
real SSA values for moderate-high aerosol loads. In a similar way, AERONET, in version 2, only provides SSA values with quality assurance if the AOD at $440 \mathrm{~nm}$ is higher than 0.4 (Dubovik et al., 2000, 2002; Holben et al., 2006). Then, most of the obtained SSA differences could be associated with the low-aerosol-load conditions, where the SSA uncertainty is high in GRASP ${ }_{\text {pac }}$ values.

\subsubsection{Volume size distribution comparison}

Figure 4 shows the comparison of the total aerosol volume concentration $(V)$ determined with GRASP $\mathrm{pac}_{\mathrm{pac}}$ and measured in situ at MSA height over the study period. The color scale represents the ratio $V_{\text {fine }} / V$ that quantifies the contribution of fine particles (diameter below $1 \mu \mathrm{m}$ ) to the total volume concentration, as determined from the in situ measurements. As we can see in Fig. 4a, there is a lack of correlation, showing a different relationship depending on the ratio $V_{\text {fine }} / V$. When fine particles predominate (i.e., $V_{\text {fine }} / V>0.75$, yellowish colors) the volume concentration measured in situ is significantly larger than the volume concentration retrieved from the ceilometer and photometer data using GRASP $\mathrm{pac}_{\text {. }}$ On the contrary, when coarse particles predominate the volume concentration provided by GRASP ${ }_{\mathrm{pac}}$ is larger than the one determined in situ. Limiting the comparison to those cases with $V_{\text {fine }} / V<0.75$ (Fig. 4b), the correlation improves significantly $\left(R^{2}=0.65\right)$ and shows absolute differences within $\pm 5 \mu \mathrm{m}^{3} \mathrm{~cm}^{-3}$ for $85 \%$ of the data (Fig. $4 \mathrm{c}$ ). Similar to the extinction and scattering coefficient comparison, GRASP $\mathrm{pac}_{\mathrm{pac}}$ retrievals yield higher aerosol volume concentrations compared with the in situ measurements. Similar overestimations comparing GRASP pac $_{\text {and in situ data }}$ have been reported before. In particular, Román et al. (2018) compared the GRASP ${ }_{\text {pac }}$ retrievals using also ceilometer and photometer data as input with in situ measurements performed in a mountain station located $\sim 25 \mathrm{~km}$ apart from the ceilometer and at around $2000 \mathrm{~m}$ above it during an intensive field campaign. Their results show that GRASP pac overestimates the volume concentration with a slope of the comparison around 1.5. We found similar results, revealing that, in general, GRASP ${ }_{\text {pac }}$ overestimates the aerosol volume concentration (slope of the comparison of 1.34). However, the comparison between GRASP ${ }_{\mathrm{pac}}$ and in situ measurements shows significant discrepancies when fine particles predominate $\left(V_{\text {fine }} / V>0.75\right)$. The reduced number of cases with $V_{\text {fine }} / V>0.75(\sim 15 \%$ of the total number of data points) makes it difficult to draw conclusive results concerning the total volume concentration in atmospheric conditions dominated by fine particles. Previous evaluations of the GRASP algorithm were mainly conducted during Saharan dust events with predominance of coarse-mode particles. Benavent-Oltra et al. (2017) found similar coarse volume concentrations between GRASP retrievals and in situ profiles during two flights performed under dust-dominated conditions, with slight underestimation of GRASP in the aloft dust plumes, while significant overestimation was reported for the fine volume concentration. Overestimation of fine volume concentrations obtained with the GARRLiC algorithm compared with in situ data was also observed under a dustdominated and a marine polluted case (Tsekeri et al., 2017). Using synthetic data, Román et al. (2018) showed higher discrepancies in the retrieval of fine volume concentrations than in coarse ones for GRASP ${ }_{\mathrm{pac}}$. The reason behind these dif- 

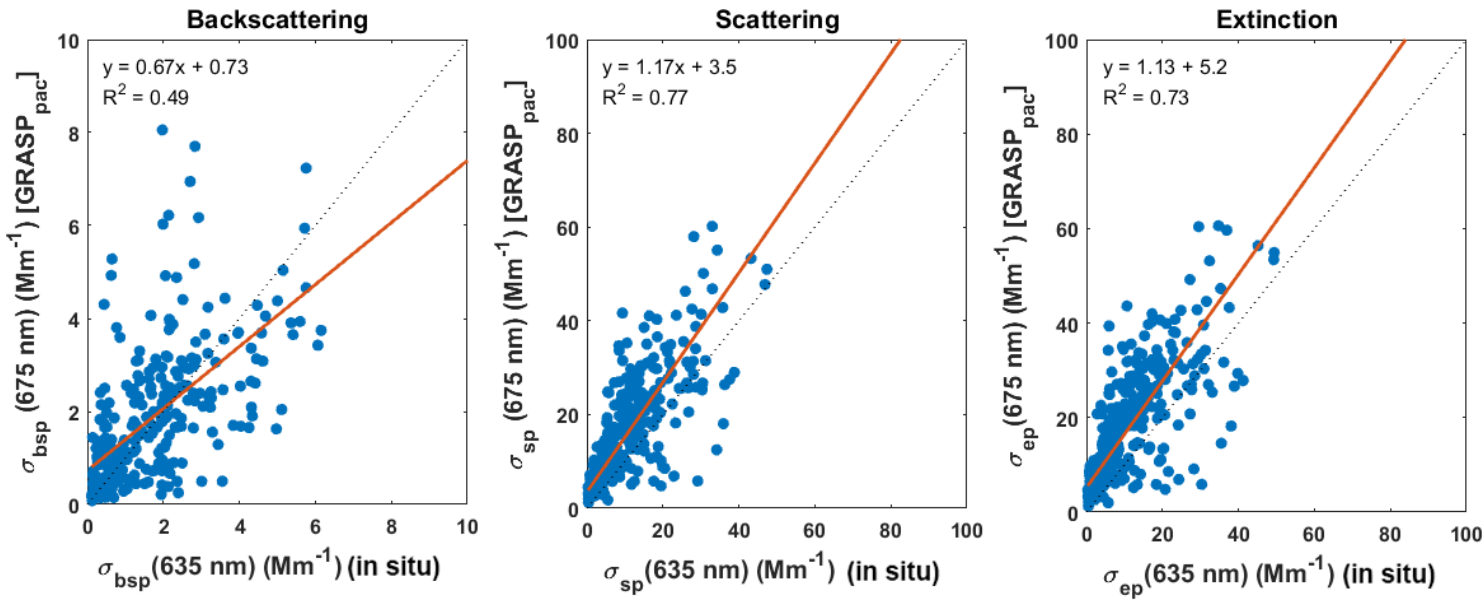

Figure 1. Scatter plots of the hourly averaged aerosol light-backscattering, scattering and extinction coefficients determined with GRASP pac from the ceilometer and photometer data at MSA height versus the measured in situ coefficients. This comparison is restricted to situations with low ambient $\mathrm{RH}\left(\mathrm{RH}_{\text {ambient }}<50 \%\right)$. The linear regression and the $1: 1$ line are also shown.
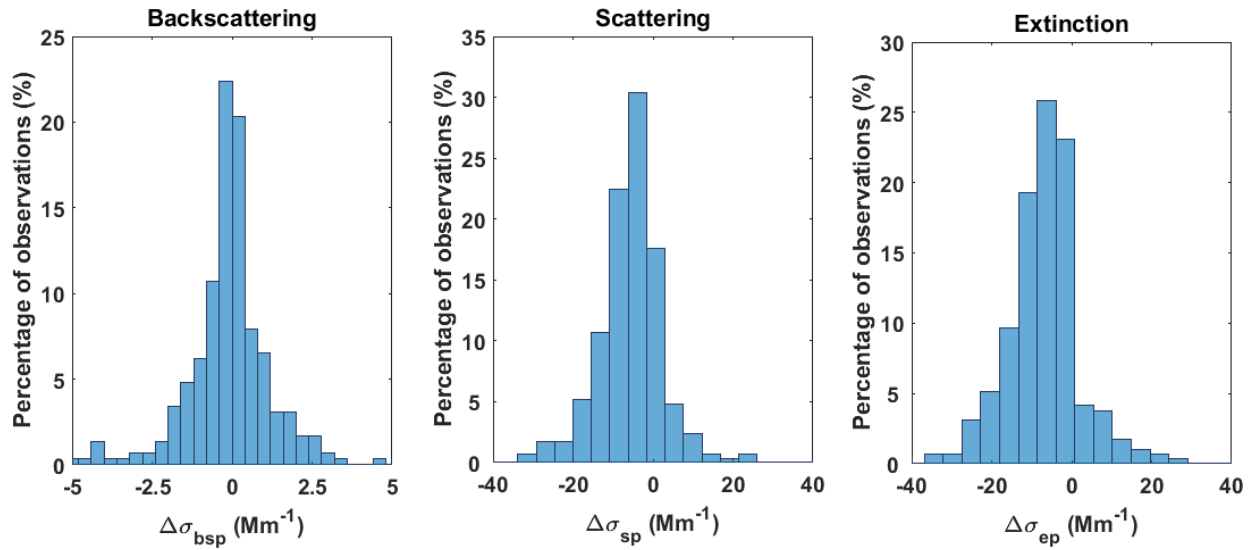

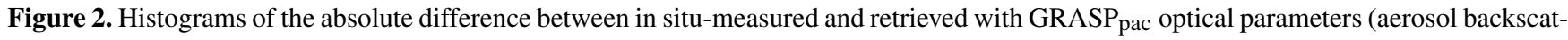
tering, scattering and extinction coefficients) at low ambient $\mathrm{RH}\left(\mathrm{RH}_{\mathrm{ambient}}<50 \%\right)$.
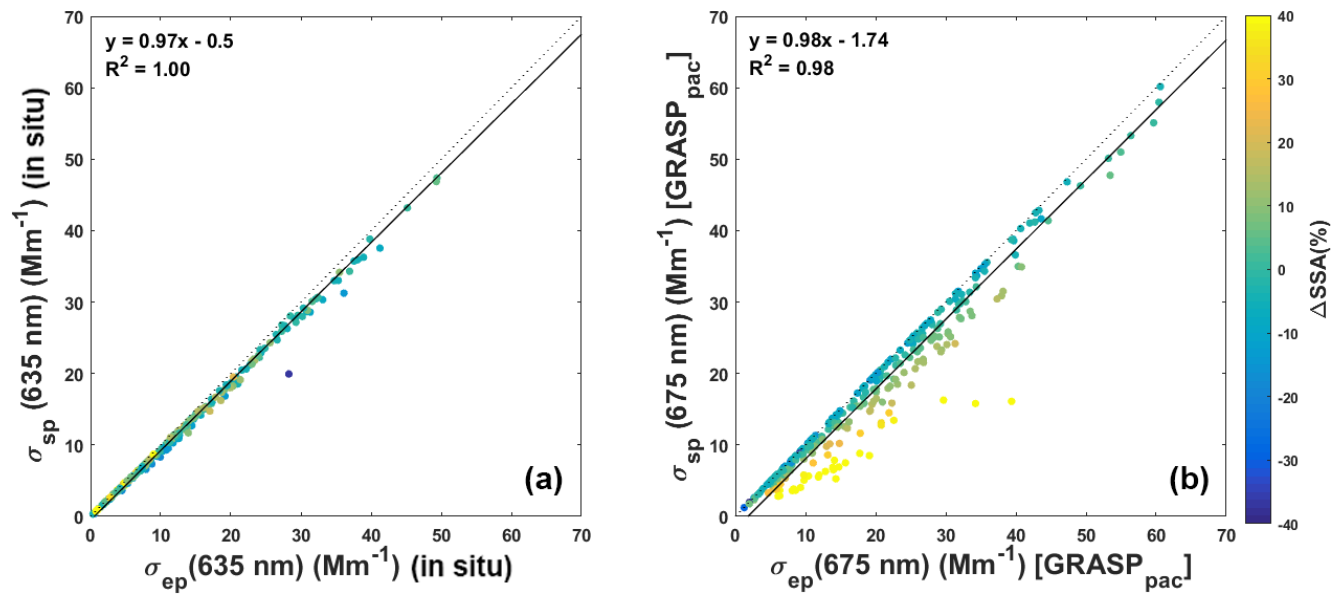

Figure 3. Scatter plots of the hourly averaged aerosol light-scattering and extinction coefficients measured in situ (a) and retrieved with

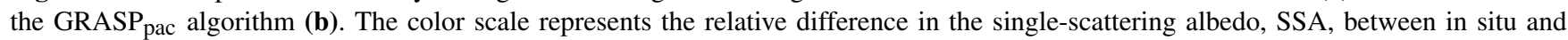
GRASP $_{\text {pac }}$ data. 

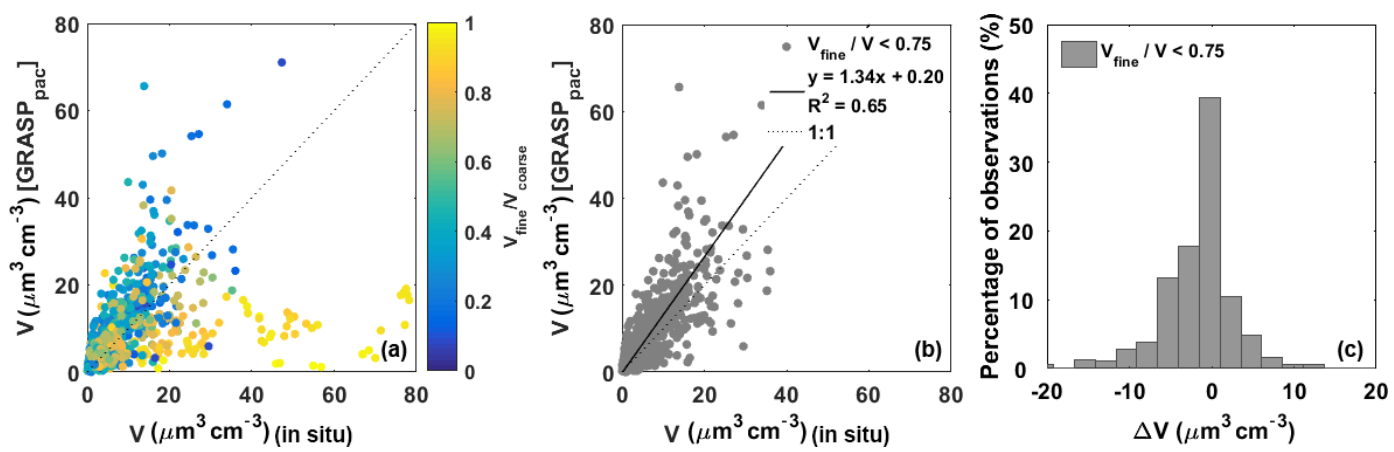

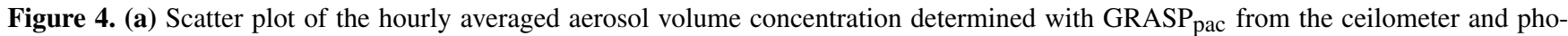
tometer data at MSA height versus the in situ concentrations at low ambient $\mathrm{RH}\left(\mathrm{RH}_{\mathrm{ambient}}<50 \%\right)$, with the color scale representing the contribution of fine particles to the total volume concentration. (b) Same as panel (a) but restricted to situations with contribution of fine particles to the total aerosol volume concentration $<75 \%\left(V_{\text {fine }} / V<0.75\right)$. (c) Frequency of occurrence of the absolute difference between the volume concentrations measured in situ and determined with GRASP pac for situations with $V_{\text {fine }} / V<0.75$.

ferences was partly attributed to the use of a long wavelength $(1064 \mathrm{~nm})$ as RCS in the retrieval which is less sensitive to fine particles than shorter wavelengths. Nevertheless, despite the differences among studies, all of them evidence that the retrieval of fine volume concentrations is particularly challenging while good results can be obtained for the coarse volume concentration or total concentration if the size distribution is dominated by coarse particles.

Finally, several environmental and topographic factors can be brought forward to partly explain the differences observed among techniques, namely the measurement atmospheric conditions (temperature, pressure and $\mathrm{RH}$ ) and orographic effects affecting wind patterns and atmospheric boundary layer (ABL) structure and causing spatial inhomogeneities. Concerning the atmospheric conditions at which the aerosol properties are measured in terms of temperature, pressure and relative humidity, we expect a low effect on the comparison since the in situ data have been converted to ambient $T$ and $P$ and the comparison was restricted to cases with ambient RH $<50 \%$. Although hygroscopic growth can occur even at low RH (Zieger et al., 2017), we limit the study to ambient $\mathrm{RH}<50 \%$ in order to minimize the RH effect in the comparison (Titos et al., 2016). As can be seen in Fig. S1 of the Supplement, the comparison shows no dependency on $\mathrm{RH}$ for $\mathrm{RH}_{\text {ambient }}<50 \%$. Another possible factor that could affect the comparison is the fact that the in situ and photometer measurements are not performed exactly over the ceilometer vertical. However, due to the short horizontal distance $(<2.5 \mathrm{~km})$, this fact is expected to have little impact on our results.

\subsection{Statistical analysis of aerosol profiles}

In the following section, we focus on the extinction coefficient since it is the most relevant climate variable from the ones retrieved with GRASP $\mathrm{pac}_{\mathrm{pa}}$. Figure 5 shows the seasonality of particle extinction profiles retrieved with GRASP $\mathrm{pac}_{\mathrm{p}}$ using ceilometer and photometer data as inputs. It is important to recall that GRASP ${ }_{\text {pac }}$ retrievals are performed only during daytime and clear-sky conditions caused by the combination of the ceilometer with the sun/sky photometer data (see Sect. 3 for further details), which might bias the statistical analysis presented in this section compared to continuous measurements. Figure S2 of the Supplement shows the frequency distribution of the number of profiles retrieved by month and hour of the day. As it can be seen, the GRASP retrievals are restricted to daytime conditions and solar zenith angles larger than $40^{\circ}$ (mainly from 6 to $9 \mathrm{~h}$ in the morning and from 14 to $16 \mathrm{~h}$ ). Accordingly, there are also fewer GRASP $_{\text {pac }}$ retrievals during autumn and winter.

In average terms, the largest extinction coefficients are observed at the lowest altitudes sounded. A nearly exponential decrease with height of the median extinction coefficients is observed during all seasons up to $4000-5000 \mathrm{~m}$ a.s.l. An exponential decreasing trend of the extinction coefficient has been observed in several statistical lidar studies in Europe (Mattis et al., 2004; Amiridis et al., 2005; Navas-Guzmán et al., 2013). There is a clear seasonal behavior in the vertical distribution of aerosol particles, evidencing that during winter most particles are confined to the first few kilometers above the surface while the median profile in summer shows the presence of particles at higher altitudes. Also in summer, the extinction profiles display a larger interquartile range compared with the other seasons, denoting high variability in the vertical distribution of aerosol particles. Concerning the extinction coefficients in the lowermost part of the profiles, Pandolfi et al. (2014) reported a similar seasonality for continuous in situ measurements at MSA, with the highest extinction coefficients observed in summer and the lowest ones in winter.

Air masses arriving at MSA have been classified into four sectors following the procedure of Ripoll et al. (2014): Atlantic (ATL), North African (NAF), Regional (REG), and Mediterranean and European (MED+EU). Figure 6 shows a 

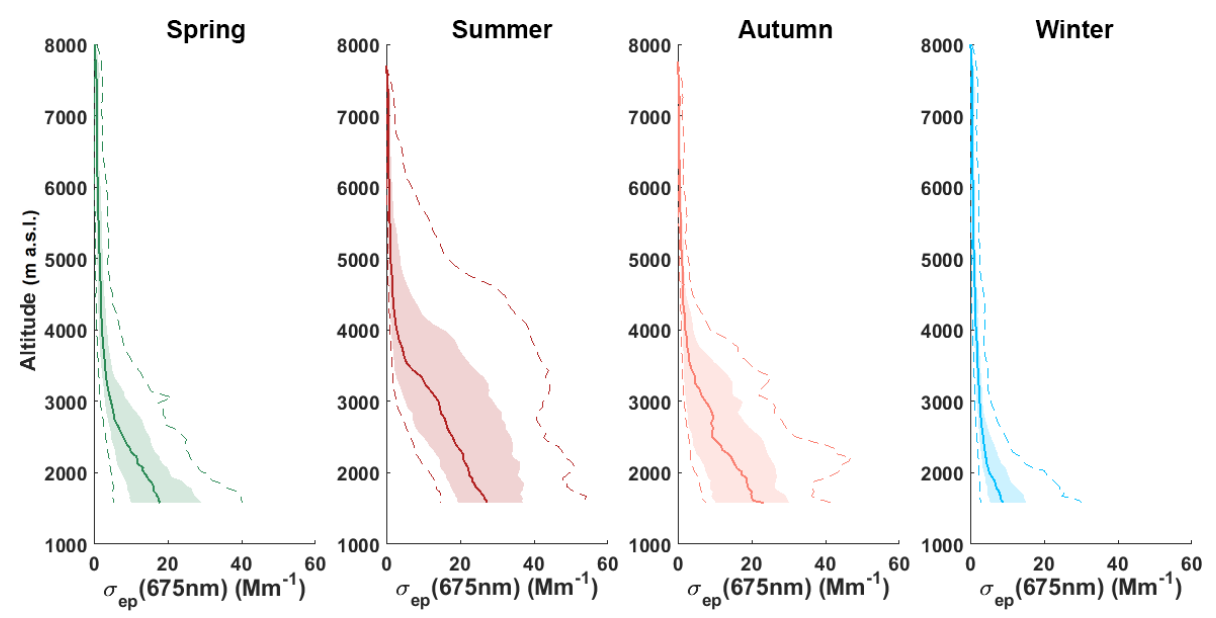

Figure 5. Seasonal variability of vertical profiles of aerosol extinction coefficients at $675 \mathrm{~nm}$. The line represents the median and the shadowed area is the interquartile range. The dashed lines represent the 10th and 90th percentiles. Seasonal statistics are based on daily averaged profiles. Spring corresponds with March, April and May; summer with June, July and August; autumn with September, October and November; and winter with December, January and February.

statistical overview of the extinction profiles from GRASP $\mathrm{pac}$ classified according with their air mass origin. There are significant differences in the extinction vertical distribution depending on the origin of the air masses affecting the Montsec area. The lowest median extinction coefficient occurs under Atlantic air masses. This result is in agreement with the low extinction coefficients found in winter, given that during colder months the site is frequently affected by Atlantic air masses and is located within the free troposphere (Ripoll et al., 2014). These profiles also show low variability (smaller interquartile range). A similar behavior is obtained for the MED+EU sector, although the extinction coefficient displays higher variability, which is especially pronounced close to the surface (high 90th percentile). For air masses with origin in North Africa the extinction coefficient vertical profiles show the highest variability, denoting the strong variation in intensity and aerosol-layer stratification among events. The average extinction coefficient for the lowest atmospheric layer is slightly lower than the average extinction coefficient found during dust events at the surface level in MSA using in situ techniques (Pandolfi et al., 2014). This discrepancy can be attributed to the different study period and therefore different NAF episodes included in the calculation with varying intensity and frequency. The air masses grouped in the REG sector include transport from the Iberian Peninsula as well as recirculation processes associated with the land-sea breezes regime (Millán et al., 1997). In this case, the extinction coefficient profiles show high variability up to $6000 \mathrm{~m}$ a.s.l., indicating layering and accumulation of pollutants under regional recirculation conditions. During these episodes, pollutants are raised up to upper levels, resulting in the stratification of aerosol layers along the vertical atmosphere (Pérez et al., 2004). On the other hand, the MED+EU and ATL sectors show a low 90th percentile and interquartile range above $3000 \mathrm{~m}$ a.s.l., suggesting that the likelihood of aloft aerosol layers under these atmospheric scenarios is significantly reduced compared with the REG sector and, more remarkable, with the NAF sector.

The air mass classification and the seasonality of the extinction vertical profiles are clearly linked. NAF and REG episodes are more frequent during spring and summer while ATL episodes are more frequent in autumn and winter (Ripoll et al., 2014). The seasonal cycle observed is mainly modulated by a higher development of the ABL during warm months and higher influence of REG and NAF episodes (e.g., Ealo et al., 2018). This combination leads to high extinction coefficients at higher altitudes and strong variability (large difference in the 10th and 90th percentiles and interquartile range) during warmer months. However, in winter, MSA is frequently influenced by free-troposphere conditions and venting periods (Ripoll et al., 2014) and therefore lower extinction coefficients. NAF episodes also affect MSA during winter (i.e., Titos et al., 2017), but their frequency of occurrence is low and their impact on the extinction vertical profile is not observed in the median and 90th percentile profiles (Fig. 6).

Figure 7 shows the center of mass calculated for the median extinction profile, as well as the 25th and 75th percentile extinction profiles following the procedure described by $\mathrm{Ca}-$ zorla et al. (2017), as a function of the air mass origin sector. The center of mass gives in a single number an indication of the altitude of the aerosol vertical distribution in the atmosphere. In cases in which a single aerosol layer is present in the atmosphere, the center of mass gives an indication of its mean altitude; in cases of multiple layers, however, it could be located in areas without any considerable aerosol load (Binietoglou et al., 2015; Mona et al., 2006). The highest center of mass is achieved under NAF air masses, evidenc- 

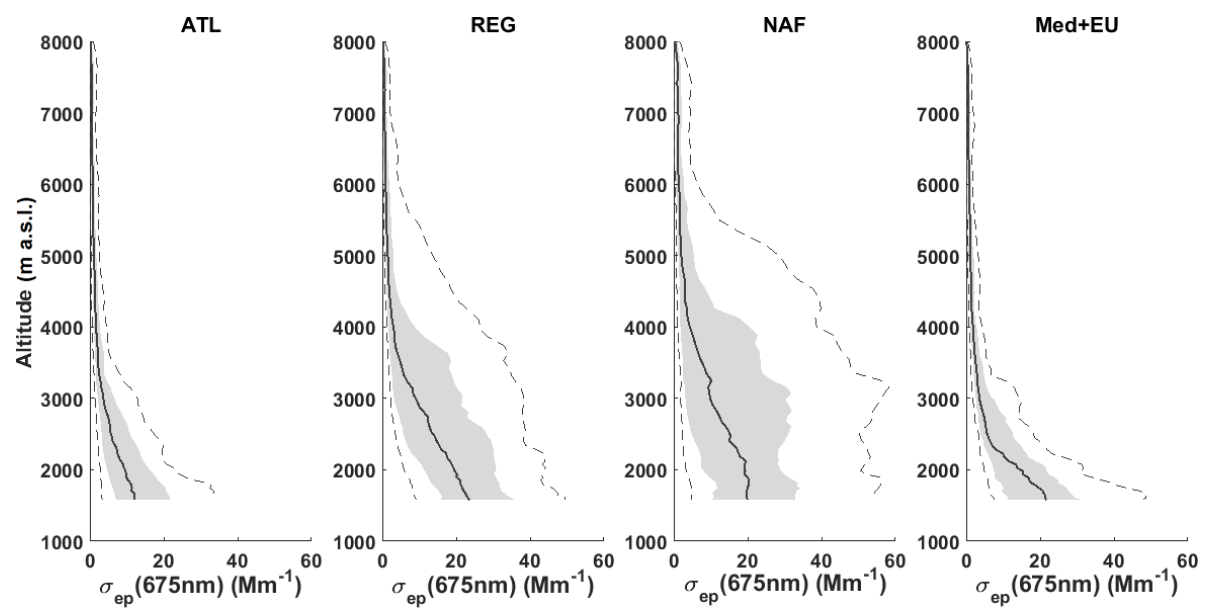

Figure 6. Particle extinction coefficient profiles at $675 \mathrm{~nm}$ classified by air mass origin (ATL: Atlantic, REG: Regional, MED+EU: Mediterranean and European, NAF: North African). The line represents the median and the shadowed area is the interquartile range. The dashed lines represent the 10th and 90th percentiles. Statistics are based on daily average profiles.

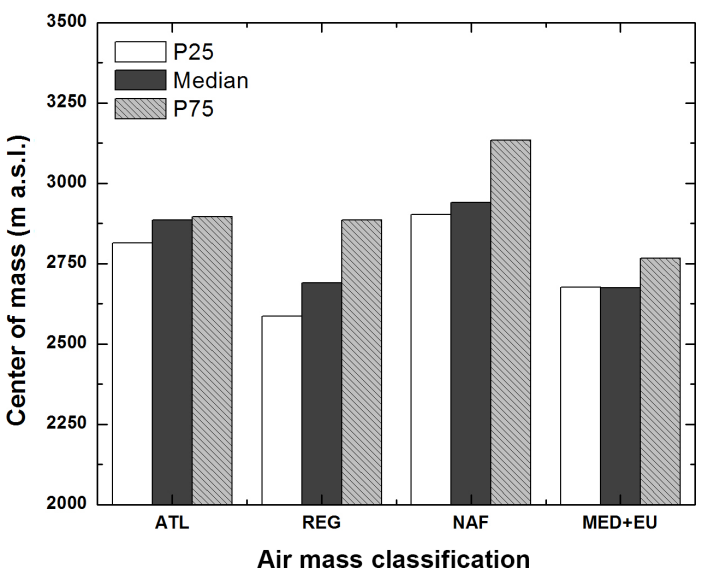

Figure 7. Bar plot of the center of mass in meters above sea level (ma.s.l.; note that the MSA observatory is at $1570 \mathrm{ma.s.1}$.) of the 25th percentile (P25), median and 75th percentile (P75) profiles, separated as a function of air mass (ATL: Atlantic, REG: Regional, MED+EU: Mediterranean and European, NAF: North African).

ing the influence of aloft dust layers. During an intense dust outbreak in February 2016, Cazorla et al. (2017) calculated a center of mass of $3000 \mathrm{~m}$ a.s.l. (1430 m a.g.l.) at MSA in the most intense day. An interesting feature of Fig. 7 is the difference in the centers of mass retrieved from the percentiles and median profiles for the REG and NAF sectors, while for ATL and MED+EU the difference in the 25th and 75th percentiles is small. This fact evidences the high variability in vertical distribution of aerosol particles occurring during NAF and REG episodes.

\section{Conclusions}

In this study, we present a systematic application of the GRASP algorithm using ceilometer RCS and sun/sky photometer measurements (GRASP ${ }_{\mathrm{pac}}$ ) over an extended period of time ( 3 years). Our unique experimental setup allows us to perform a long-term evaluation of the GRASP $_{\text {pac }}$ retrievals versus in situ measurements under different atmospheric conditions. The output variables studied here are the aerosol backscattering, scattering and extinction coefficients and the volume concentration. The results show an overall good agreement between GRASP retrievals and in situ measurements, especially good for scattering and extinction coefficients $\left(R^{2}>0.7\right)$. The volume concentration comparison shows differences depending on the predominance of fine or coarse particles, with poor agreement when the contribution of fine particles to the total volume concentration is $>75 \%$ and good agreement otherwise. Restricting the comparison to cases with $V_{\text {fine }} / V<0.75$, GRASP ${ }_{\text {pac }}$ and in situ measurements show good correlation although GRASP pac yields higher volume concentrations. A similar overestimation of GRASP $\mathrm{pac}_{\text {is }}$ found for the scattering and extinction coefficients. We found slight discrepancies in the scatteringextinction relationship obtained with GRASP $\mathrm{Pac}_{\mathrm{p}}$ compared to in situ data. In general, GRASP ${ }_{\mathrm{pac}}$ retrievals yield lower SSA values (average SSA of $0.88 \pm 0.14$ ) compared with in situ SSA $(0.93 \pm 0.04)$. This result can be linked with previous evaluations of AERONET retrievals that were shown to yield higher aerosol absorption than in situ measurements, especially at low aerosol load. Evaluation of the GRASP pac $_{\text {, }}$ algorithm at different environments with variable aerosol load and SSA characteristics will contribute to better understanding and constraining the validity and limitations of GRASP $_{\text {pac }}$. 
The statistical analysis of the extinction coefficient vertical profiles retrieved with GRASP ${ }_{\text {pac }}$ shows a clear seasonality as well as significant differences depending on the air mass origin. The observed seasonal cycle is characterized by higher extinction coefficients during summer with strong day-to-day variability, while during winter the extinction coefficient is lower in the whole atmospheric column and shows lower variability. This seasonality is associated with a higher development of the atmospheric boundary layer during warm months, favoring the transport of pollutants to MSA. Additionally, the higher influence of regional and North African episodes in summer contributes to the observed seasonality. On the other hand, in winter, MSA is frequently influenced by free-troposphere conditions and venting periods and therefore lower extinction coefficients that markedly decrease with height.

The use of automated lidars and ceilometers systems for the determination of vertically resolved aerosol properties has increased in recent years thanks to their low operation requirements and costs, as well as their capability of providing continuous unattended measurements. Together with this increased use of ceilometer systems, there is a growing need for being able to convert the ceilometer signals into usable aerosol properties. In this context, the overall good results obtained in our validation are encouraging and emphasize the potentiality of implementing GRASP in ceilometer and lidar networks for obtaining aerosol optical properties and volume concentrations with height resolution and wide spatial coverage. Compared with previous studies, the present evaluation of GRASP ${ }_{\text {pac }}$ retrievals with in situ data has been performed over a 3-year period, being therefore representative of varying atmospheric conditions. Nevertheless, it is important to bear in mind that the results presented in this study are limited to daytime and low-cloudiness conditions due to the need for simultaneous sun/sky photometer measurements. Also, further studies investigating the performance of the applica-

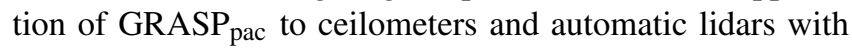
different characteristics (i.e., wavelength of operation, pulse energy) than the one used in this study are needed to maximize its potential application. With this in mind, the implementation of GRASP ${ }_{\text {pac }}$ in the frame of measurement networks will contribute to enhancing the representativeness of the aerosol vertical distribution as well as to providing useful information for satellite and models evaluation, in addition to contributing to the objectives of several international initiatives (Illingworth et al., 2019) such us the EU COST Action TOPROF (Towards operational ground-based profiling with ceilometers, Doppler lidars and microwave radiometers for improving weather forecasts) or the E-PROFILE program of the European Meteorological Services Network.

Data availability. Sun-photometer data are accessible on the AERONET website (http://aeronet.gsfc.nasa.gov/, last access: 17 June 2019). In situ data measured at MSA are accessible on a yearly basis at the World Data Center for Aerosols website (http: //ebas.nilu.no/, last access: 17 June 2019). Ceilometer data and in situ raw data are available from the authors upon request.

Supplement. The supplement related to this article is available online at: https://doi.org/10.5194/amt-12-3255-2019-supplement.

Author contributions. GT analyzed the data and wrote the manuscript, ME operated the MSA in situ station, RR performed the GRASP retrievals, AC processed the ceilometer data in the frame of ICENET, YS operated the sun/sky photometer at MSA, OD provided feedback on the GRASP algorithm, AA designed the experiment, and MP operated the ceilometer and designed the experiment. All authors provided comments on the manuscript.

Competing interests. The authors declare that they have no conflict of interest.

Acknowledgements. Marco Pandolfi is funded by a Ramón y Cajal Fellowship (RYC-2013-14036) awarded by MINECO. Roberto Román is funded by MINECO under postdoctoral program Juan de la Cierva - Incorporación (IJCI-2016-30007). Gloria Titos is funded by MINECO under postdoctoral program Juan de la Cierva (FJCI-2014-20819 and IJCI-2016-29838). We thank the OAdM and COU astronomical observatories for their support. Thanks are due to the AERONET and RIMA networks for the scientific and technical support. The MODIS MCD43C1 data product was retrieved from the online Data Pool, courtesy of the NASA Land Processes Distributed Active Archive Center (LP DAAC), USGS/Earth Resources Observation and Science (EROS) Center. The authors acknowledge the use of the GRASP inversion algorithm (https://www.grasp-open.com/) and also thank David Fuertes, Anton Lopatín and Benjamín Torres for their feedback in the use of GRASP.

Financial support. This research has been supported by the Spanish Ministry of Science and Education (grant nos. CGL2012-39623C02/00 and CGL2016-78594-R), the Generalitat Catalunya (grant no. AGAUR 2017 SGR0041) and the H2020 Research Infrastructures (ACTRIS-2, grant no. 654109).

Review statement. This paper was edited by Jun Wang and reviewed by three anonymous referees.

\section{References}

Amiridis, V., Balis, D. S., Kazadzis, S., Bais, A., Giannakaki, E., Papayannis, A., and Zerefos, C.: Four-year aerosol observations with a Raman lidar at Thessaloniki, Greece, in the framework of European Aerosol Research Li- 
dar Network (EARLINET), J. Geophys. Res., 110, D21203, https://doi.org/10.1029/2005JD006190, 2005.

Anderson, T. L., Covert, D. S., Marshall, S. F., Laucks, M. L., Charlson, R. J., Waggoner, A. P., Ogren, J. A., Caldow, R., Holm, R. L., Quant, F. R., Sem, G. J., Wiedensohler, A., Ahlquist, N. A., and Bates, T. S.: Performance characteristics of a high-sensitivity, three-wavelength, total scatter/backscatter nephelometer, J. Atmos. Ocean. Tech., 13, 967-986, 1996.

Andrews, E., Ogren, J. A., Kinne, S., and Samset, B.: Comparison of AOD, AAOD and column single scattering albedo from AERONET retrievals and in situ profiling measurements, Atmos. Chem. Phys., 17, 6041-6072, https://doi.org/10.5194/acp17-6041-2017, 2017.

Benavent-Oltra, J. A., Román, R., Granados-Muñoz, M. J., PérezRamírez, D., Ortiz-Amezcua, P., Denjean, C., Lopatin, A., Lyamani, H., Torres, B., Guerrero-Rascado, J. L., Fuertes, D., Dubovik, O., Chaikovsky, A., Olmo, F. J., Mallet, M., and Alados-Arboledas, L.: Comparative assessment of GRASP algorithm for a dust event over Granada (Spain) during ChArMExADRIMED 2013 campaign, Atmos. Meas. Tech., 10, 44394457, https://doi.org/10.5194/amt-10-4439-2017, 2017.

Binietoglou, I., Basart, S., Alados-Arboledas, L., Amiridis, V., Argyrouli, A., Baars, H., Baldasano, J. M., Balis, D., Belegante, L., Bravo-Aranda, J. A., Burlizzi, P., Carrasco, V., Chaikovsky, A., Comerón, A., D’Amico, G., Filioglou, M., Granados-Muñoz, M. J., Guerrero-Rascado, J. L., Ilic, L., Kokkalis, P., Maurizi, A., Mona, L., Monti, F., Muñoz-Porcar, C., Nicolae, D., Papayannis, A., Pappalardo, G., Pejanovic, G., Pereira, S. N., Perrone, M. R., Pietruczuk, A., Posyniak, M., Rocadenbosch, F., Rodríguez-Gómez, A., Sicard, M., Siomos, N., Szkop, A., Terradellas, E., Tsekeri, A., Vukovic, A., Wandinger, U., and Wagner, J.: A methodology for investigating dust model performance using synergistic EARLINET/AERONET dust concentration retrievals, Atmos. Meas. Tech., 8, 3577-3600, https://doi.org/10.5194/amt-8-3577-2015, 2015.

Cazorla, A., Casquero-Vera, J. A., Román, R., Guerrero-Rascado, J. L., Toledano, C., Cachorro, V. E., Orza, J. A. G., Cancillo, M. L., Serrano, A., Titos, G., Pandolfi, M., Alastuey, A., Hanrieder, N., and Alados-Arboledas, L.: Near-real-time processing of a ceilometer network assisted with sun-photometer data: monitoring a dust outbreak over the Iberian Peninsula, Atmos. Chem. Phys., 17, 11861-11876, https://doi.org/10.5194/acp-17-118612017, 2017.

Chaikovsky, A., Dubovik, O., Goloub, P., Balashevich, N., Lopatsin, A., Karol, Y., Denisov, S., and Lapyonok, T.: Software package for the retrieval of aerosol microphysical properties in the vertical column using combined lidar/photometer data (test version), Technical Report, Institute of Physics, National Academy of Sciences of Belarus, Minsk, Belarus, 2008.

Chaikovsky, A., Dubovik, O., Holben, B., Bril, A., Goloub, P., Tanré, D., Pappalardo, G., Wandinger, U., Chaikovskaya, L., Denisov, S., Grudo, J., Lopatin, A., Karol, Y., Lapyonok, T., Amiridis, V., Ansmann, A., Apituley, A., Allados-Arboledas, L., Binietoglou, I., Boselli, A., D’Amico, G., Freudenthaler, V., Giles, D., Granados-Muñoz, M. J., Kokkalis, P., Nicolae, D., Oshchepkov, S., Papayannis, A., Perrone, M. R., Pietruczuk, A., Rocadenbosch, F., Sicard, M., Slutsker, I., Talianu, C., De Tomasi, F., Tsekeri, A., Wagner, J., and Wang, X.: Lidar-Radiometer Inversion Code (LIRIC) for the retrieval of vertical aerosol prop- erties from combined lidar/radiometer data: development and distribution in EARLINET, Atmos. Meas. Tech., 9, 1181-1205, https://doi.org/10.5194/amt-9-1181-2016, 2016.

Chen, C., Dubovik, O., Henze, D. K., Lapyonak, T., Chin, M., Ducos, F., Litvinov, P., Huang, X., and Li, L.: Retrieval of desert dust and carbonaceous aerosol emissions over Africa from POLDER/PARASOL products generated by the GRASP algorithm, Atmos. Chem. Phys., 18, 12551-12580, https://doi.org/10.5194/acp-18-12551-2018, 2018.

Dionisi, D., Barnaba, F., Diémoz, H., Di Liberto, L., and Gobbi, G. P.: A multiwavelength numerical model in support of quantitative retrievals of aerosol properties from automated lidar ceilometers and test applications for AOT and $\mathrm{PM}_{10}$ estimation, Atmos. Meas. Tech., 11, 6013-6042, https://doi.org/10.5194/amt11-6013-2018, 2018.

Dubovik, O. and King, M. D.: A flexible inversion algorithm for retrieval of aerosol optical properties from sun and sky radiance measurements, J. Geophys. Res.-Atmos. 105, 20673 20696, 2000.

Dubovik, O., Smirnov, A., Holben, B. N., King, M. D., Kaufman, Y. J., Eck, T. F., and Slutsker, I.: Accuracy assessments of aerosol optical properties retrieved from Aerosol Robotic Network (AERONET) Sun and sky radiance measurements, J. Geophys. Res.-Atmos., 105, 9791-9806, 2000.

Dubovik, O., Holben, B., Eck, T. F., Smirnov, A., Kaufman, Y. J., King, M. D., Tanré, D., and Slutsker, I.: Variability of absorption and optical properties of key aerosol types observed in worldwide locations, J. Atmos. Sci., 59, 590-608, 2002.

Dubovik, O., Sinyuk, A., Lapyonok, T., Holben, B.N., Mishchenko, M., Yang, P., Eck, T., Volten, H., Munoz, O., Veihelmann, B., Van Der Zande, W.J., Leon, J., Sorokin, M., and Slutsker, I.: Application of spheroid models to account for aerosol particle nonsphericity in remote sensing of desert dust, J. Geophys. Res.Atmos. 111, D11208, https://doi.org/10.1029/2005JD006619, 2006.

Dubovik, O., Herman, M., Holdak, A., Lapyonok, T., Tanré, D., Deuzé, J. L., Ducos, F., Sinyuk, A., and Lopatin, A.: Statistically optimized inversion algorithm for enhanced retrieval of aerosol properties from spectral multi-angle polarimetric satellite observations, Atmos. Meas. Tech., 4, 975-1018, https://doi.org/10.5194/amt-4-975-2011, 2011.

Dubovik, O., Lapyonok, T., Litvinov, P., Herman, M., Fuertes, D., Ducos, F., Lopatin, A., Chaikovsky, A., Torres, B., Derimian, Y., Huang, X., Aspetsberger, M., and Federspiel, C.: GRASP: A Versatile Algorithm for Characterizing the Atmosphere, SPIE Newsroom, https://doi.org/10.1117/2.1201408.005558, 2014.

Ealo, M., Alastuey, A., Ripoll, A., Pérez, N., Minguillón, M. C., Querol, X., and Pandolfi, M.: Detection of Saharan dust and biomass burning events using near-real-time intensive aerosol optical properties in the north-western Mediterranean, Atmos. Chem. Phys., 16, 12567-12586, https://doi.org/10.5194/acp-1612567-2016, 2016.

Ealo, M., Alastuey, A., Pérez, N., Ripoll, A., Querol, X., and Pandolfi, M.: Impact of aerosol particle sources on optical properties in urban, regional and remote areas in the northwestern Mediterranean, Atmos. Chem. Phys., 18, 1149-1169, https://doi.org/10.5194/acp-18-1149-2018, 2018.

Espinosa, W. R., Remer, L. A., Dubovik, O., Ziemba, L., Beyersdorf, A., Orozco, D., Schuster, G., Lapyonok, T., Fuertes, 
D., and Martins, J. V.: Retrievals of aerosol optical and microphysical properties from Imaging Polar Nephelometer scattering measurements, Atmos. Meas. Tech., 10, 811-824, https://doi.org/10.5194/amt-10-811-2017, 2017.

Granados-Muñoz, M. J., Sicard, M., Román, R., Benavent-Oltra, J. A., Barragán, R., Brogniez, G., Denjean, C., Mallet, M., Formenti, P., Torres, B., and Alados-Arboledas, L.: Impact of mineral dust on shortwave and longwave radiation: evaluation of different vertically resolved parameterizations in 1-D radiative transfer computations, Atmos. Chem. Phys., 19, 523-542, https://doi.org/10.5194/acp-19-523-2019, 2019.

Grimm, H. and Eatough, D. J.: Aerosol measurement: The use of optical light scattering for the determination of particulate size distribution, and particulate mass, including the semivolatile fraction, J. Air Waste Manage. Assoc., 59, 101-107, https://doi.org/10.3155/1047-3289.59.1.101, 2009.

Herreras, M., Román, R., Cazorla, A., Toledano, C., Lyamani, H., Torres, B., Cachorro, V.E., Olmo, F.J., Alados-Arboledas, L., and de Frutos, A. M.: Integrated Aerosol Extinction Profiles from Ceilometer and Sunphotometer Combination against Sunphotometer Measurements at Various Heights. IGARSS 20182018 IEEE International Geoscience and Remote Sensing Symposium, IEEE, 22-27 July 2018, Valencia, Spain, 7564-7567, 2018.

Holben, B. N., Eck, T. F., Slutsker, I., Tanré, D., Buis, J. P., Setzer, A., Vermote, E., Reagan, J. A., Kaufman, Y. J., Nakajima, T., Lavenu, F., Jankowiak, I., and Smirnov, A.: AERONET - a federated instrument network and data archive for aerosol characterization, Remote Sens. Environ., 66, 1-16, 1998.

Holben, B. N., Eck, T. F., Slutsker, I., Smirnov, A., Sinyuk, A., Schafer, J., Giles, D., and Dubovik, O.: AERONET's version 2.0 quality assurance criteria. Proc. SPIE 6408, Remote Sensing of the Atmosphere and Clouds, 64080Q, https://doi.org/10.1117/12.706524, 2006.

Illingworth, A., Cimini, D., Haefele, A., Haeffelin, M., Hervo, M., Kotthaus, S., Löhnert, U., Martinet, P., Mattis, I., O’Connor, E., and Potthast, R.: How can Existing Ground-Based Profiling Instruments Improve European Weather Forecasts?, B. Am. Meteorol. Soc., 605-619, https://doi.org/10.1175/BAMS-D-17-0231.1, 2019.

Intergovernmental Panel on Climate Change (IPCC): Contribution of Working Group I to the Fifth Assessment Report of the Intergovernmental Panel on Climate Change, in Summary for Policymakers in Climate Change, edited by: Stocker, T. F., Qin, D., Plattner, G.-K., Tignor, M., Allen, S. K., Boschung, J., Nauels, A., Xia, Y., Bex, V., and Midgley, P. M., 590-600, Cambridge Univ. Press, New York, USA, 2013.

Kokhanovsky, A. A., Davis, A. B., Cairns, B., Dubovik, O., Hasekamp, O. P., Sano, I., Mukai, S., Rozanov, V. V., Litvinov, P., Lapyonok, T., Kolomiets, I. S., Oberemok, Y. A., Savenkov, S., Martin, W., Wasilewski, A., Di Noia, A., Stap, F. A., Rietjens, J., Xu, F., Natraj, V., Duan, M., Cheng, T., and Munro, R.: Space-based remote sensing of atmospheric aerosols: the multiangle spectro-polarimetric frontier, Earth Sci. Rev., 145, 85-116, https://doi.org/10.1016/j.earscirev.2015.01.012, 2015.

Lopatin, A., Dubovik, O., Chaikovsky, A., Goloub, P., Lapyonok, T., Tanré, D., and Litvinov, P.: Enhancement of aerosol characterization using synergy of lidar and sun-photometer coincident observations: the GARRLiC algorithm, Atmos. Meas. Tech., 6, 2065-2088, https://doi.org/10.5194/amt-6-2065-2013, 2013.

Martucci, G., Milroy, C., and O'Dowd, C. D.: Detection of cloudbase height using Jenoptik CHM15K and Vaisala CL31 ceilometers, J. Atmos. Ocean. Tech., 2, 305-318, 2010.

Mattis, I., Ansmann, A., Muller, D., Wandinger, U., and Althausen, D.: Multiyear aerosol observations with dual wavelength Raman lidar in the framework of EARLINET, J. Geophys. Res.-Atmos., 109, D13203, https://doi.org/10.1029/2004JD004600, 2004.

Millán, M. M., Salvador, R., Mantilla, E., and Kallos, G.: Photooxidant dynamics in the Mediterranean basin in summer: Results from European research projects, J. Geophys. Res., 102, 8811, https://doi.org/10.1029/96JD03610, 1997.

Mona, L., Amodeo, A., Pandolfi, M., and Pappalardo, G.: Saharan dust intrusions in the Mediterranean area: Three years of Raman lidar measurements, J. Geophys. Res., 111, D16203, https://doi.org/10.1029/2005JD006569, 2006.

Müller, T., Laborde, M., Kassell, G., and Wiedensohler, A.: Design and performance of a three-wavelength LED-based total scatter and backscatter integrating nephelometer, Atmos. Meas. Tech., 4, 1291-1303, https://doi.org/10.5194/amt-4-1291-2011, $2011 \mathrm{a}$.

Müller, T., Henzing, J. S., de Leeuw, G., Wiedensohler, A., Alastuey, A., Angelov, H., Bizjak, M., Collaud Coen, M., Engström, J. E., Gruening, C., Hillamo, R., Hoffer, A., Imre, K., Ivanow, P., Jennings, G., Sun, J. Y., Kalivitis, N., Karlsson, H., Komppula, M., Laj, P., Li, S.-M., Lunder, C., Marinoni, A., Martins dos Santos, S., Moerman, M., Nowak, A., Ogren, J. A., Petzold, A., Pichon, J. M., Rodriquez, S., Sharma, S., Sheridan, P. J., Teinilä, K., Tuch, T., Viana, M., Virkkula, A., Weingartner, E., Wilhelm, R., and Wang, Y. Q.: Characterization and intercomparison of aerosol absorption photometers: result of two intercomparison workshops, Atmos. Meas. Tech., 4, 245-268, https://doi.org/10.5194/amt-4-245-2011, 2011 b.

Navas-Guzmán, F., Bravo-Aranda, J. A., Guerrero-Rascado, J. L., Granados-Muñoz, M. J., and Alados-Arboledas, L.: Statistical analysis of aerosol optical properties retrieved by Raman lidar over Southeastern Spain, Tellus B, 65, 21234, https://doi.org/10.3402/tellusb.v65i0.21234, 2013.

Pandolfi, M., Ripoll, A., Querol, X., and Alastuey, A.: Climatology of aerosol optical properties and black carbon mass absorption cross section at a remote high-altitude site in the western Mediterranean Basin, Atmos. Chem. Phys., 14, 6443-6460, https://doi.org/10.5194/acp-14-6443-2014, 2014.

Pérez, C., Sicard, M., Jorba, O., Comerón, A., and Baldasano, J. M.: Summertime re-circulations of air pollutants over the northeastern Iberian coast observed from systematic EARLINET lidar measurements in Barcelona, Atmos. Environ., 38, 3983-4000, https://doi.org/10.1016/j.atmosenv.2004.04.010, 2004.

Petzold, A. and Schönlinner, M.: Multi-angle absorption photometry - A new method for the measurement of aerosol light absorption and atmospheric black carbon, J. Aerosol Sci., 35, 421-441, https://doi.org/10.1016/j.jaerosci.2003.09.005, 2004.

Ripoll, A., Pey, J., Minguillón, M. C., Pérez, N., Pandolfi, M., Querol, X., and Alastuey, A.: Three years of aerosol mass, black carbon and particle number concentrations at Montsec (southern Pyrenees, 1570 ma.s.1.), Atmos. Chem. Phys., 14, 4279-4295, https://doi.org/10.5194/acp-14-4279-2014, 2014.

Román, R., Torres, B., Fuertes, D., Cachorro, V.E., Dubovik, O., Toledano, C., Cazorla, A., Barreto, A., Bosch, J. L., 
Lapyonok, T., González, R., Goloub, P., Perrone, M. R., Olmo, F. J., de Frutos, A., and Alados-Arboledas, L.: Remote sensing of lunar aureole with a sky camera: adding information in the nocturnal retrieval of aerosol properties with GRASP code, Remote Sens. Environ., 196, 238-252, https://doi.org/10.1016/j.rse.2017.05.013, 2017.

Román, R., Benavent-Oltra, J. A., Casquero-Vera, J. A., Lopatin, A., Cazorla, A., Lyamani, H., Denjean, C., Fuertes, D., PérezRamírez, D., Torres, B., Toledano, C., Dubovik, O., Cachorro, V. E., de Frutos, A. M., Olmo, F. J., and Alados-Arboledas, L.: Retrieval of aerosol profiles combining sunphotometer and ceilometer measurements in GRASP code, Atmos. Res., 204, 161-177, https://doi.org/10.1016/j.atmosres.2018.01.021, 2018.

Rosati, B., Herrmann, E., Bucci, S., Fierli, F., Cairo, F., Gysel, M., Tillmann, R., Größ, J., Gobbi, G. P., Di Liberto, L., Di Donfrancesco, G., Wiedensohler, A., Weingartner, E., Virtanen, A., Mentel, T. F., and Baltensperger, U.: Studying the vertical aerosol extinction coefficient by comparing in situ airborne data and elastic backscatter lidar, Atmos. Chem. Phys., 16, 4539-4554, https://doi.org/10.5194/acp-16-4539-2016, 2016.

Schaaf, C. L. B., Liu, J., Gao, F., and Strahler, A. H.: MODIS Albedo and Reflectance Anisotropy Products from Aqua and Terra, in: Land Remote Sensing and Global Environmental Change: NASA's Earth Observing System and the Science of ASTER and MODIS, Remote Sensing and Digital Image Processing Series, 11, edited by: Ramachandran, B., Justice, C., and Abrams, M., Springer-Cerlag, New York, USA, 549-561, 2011.

Titos, G., Cazorla, A., Zieger, P., Andrews, E., Lyamani, H., Granados-Muñoz, M. J., Olmo, F. J., and AladosArboledas, L.: Effect of hygroscopic growth on the aerosol light-scattering coefficient: A review of measurements, techniques and error sources, Atmos. Environ., 141, 494-507, https://doi.org/10.1016/j.atmosenv.2016.07.021, 2016.

Titos, G., Ealo, M., Pandolfi, M., Pérez, N., Sola, Y., Sicard, M., Comerón, A., Querol, X., and Alastuey, A.: Spatiotemporal evolution of a severe Winter dust event in the western Mediterranean: Aerosol optical and physical properties, J. Geophys. Res.-Atmos., 122, 4052-4069, https://doi.org/10.1002/2016JD026252, 2017.
Torres, B., Dubovik, O., Fuertes, D., Schuster, G., Cachorro, V. E., Lapyonok, T., Goloub, P., Blarel, L., Barreto, A., Mallet, M., Toledano, C., and Tanré, D.: Advanced characterisation of aerosol size properties from measurements of spectral optical depth using the GRASP algorithm, Atmos. Meas. Tech., 10, 3743-3781, https://doi.org/10.5194/amt-10-3743-2017, 2017.

Tsekeri, A., Lopatin, A., Amiridis, V., Marinou, E., Igloffstein, J., Siomos, N., Solomos, S., Kokkalis, P., Engelmann, R., Baars, H., Gratsea, M., Raptis, P. I., Binietoglou, I., Mihalopoulos, N., Kalivitis, N., Kouvarakis, G., Bartsotas, N., Kallos, G., Basart, S., Schuettemeyer, D., Wandinger, U., Ansmann, A., Chaikovsky, A. P., and Dubovik, O.: GARRLiC and LIRIC: strengths and limitations for the characterization of dust and marine particles along with their mixtures, Atmos. Meas. Tech., 10, 4995-5016, https://doi.org/10.5194/amt-10-4995-2017, 2017.

Wiegner, M. and Geiß, A.: Aerosol profiling with the Jenoptik ceilometer CHM15kx, Atmos. Meas. Tech., 5, 1953-1964, https://doi.org/10.5194/amt-5-1953-2012, 2012.

Wiegner, M., Madonna, F., Binietoglou, I., Forkel, R., Gasteiger, J., Geiß, A., Pappalardo, G., Schäfer, K., and Thomas, W.: What is the benefit of ceilometers for aerosol remote sensing? An answer from EARLINET, Atmos. Meas. Tech., 7, 1979-1997, https://doi.org/10.5194/amt-7-1979-2014, 2014.

World Meteorological Organization (WMO): Aerosol measurement procedures guidelines and recommendations, GAW Rep. 153, 72 pp., Geneva, Switzerland, 2003.

Zieger, P., Väisänen, O., Corbin, J. C., Partridge, D. G., Bastelberger, S., Mousavi-Fard, M., Rosati, B., Gysel, M., Krieger, U. K., Leck, C., Nenes, A., Riipinen, I., Virtanen, A., and Salter, M. E.: Revising the hygroscopicity of inorganic sea salt particles, Nat. Commun., 8,15883, https://doi.org/10.1038/ncomms15883, 2017. 